\title{
Environmental Accounting Information Disclosure in Steel Industry
}

\author{
Ran Liu \\ College of Economics and Management \\ Dalian University \\ Dalian, China \\ liuran@dlu.edu.cn
}

\begin{abstract}
The main body of environmental accounting information disclosure in China is listed companies, and the steel industry is one of the $\mathbf{1 6}$ heavily polluted industries. Steel listed companies in Shanghai and Shenzhen stock markets are taken as examples for analysis and discussion in this paper. The relevant concepts of environmental accounting and the theoretical basis of environmental accounting information disclosure are firstly described. Then the current situation of environmental accounting information disclosure in China's steel industry from disclosure method and disclosure content is analyzed to take China's steel listed companies as an example. The analysis of the status quo of environmental information disclosure in the steel industry, and the main problems and causes are drawn. Finally, some countermeasures and suggestions to improve the quality of environmental accounting information disclosure in China's steel industry are proposed.
\end{abstract}

Keywords—Environmental accounting; Information disclosure; Steel industry

\section{INTRODUCTION}

China's social and economic development level has greatly improved with the rapid development of science and technology since the 21st century. At the same time, environmental damage is becoming more and more serious. In order to seek self-interest and at the expense of the environment, many steel firms emit large amounts of pollutants such as waste water, waste gas and solid waste. It not only pollutes water quality and air, but also poses a serious threat to the survival and development of mankind. Therefore, it is of great urgent to guide firms to take the road of green production and urge firms to find a balance between economic benefits and environmental protection. Under this demand, the useful supplement of traditional accounting - environmental accounting comes into being.

Environmental accounting is a subset of accounting proper, its target being to incorporate both economic and environmental information [1-4]. It can be conducted at the corporate level or at the level of a national economy through the System of Integrated Environmental and Economic Accounting, a satellite system to the National Accounts of Countries (among other things, the National Accounts produce the estimates of Gross Domestic Product otherwise known as GDP). Environmental accounting is a field that identifies resource use, measures and communicates costs of a company's or national economic impact on the environment [5].
Costs include costs to clean up or remediate contaminated sites, environmental fines, penalties and taxes, purchase of pollution prevention technologies and waste management costs. Environmental accounting is a branch of accounting, and environmental accounting information disclosure is one of the effective ways to govern the environment. Accounting control can effectively solve the structural problems of energy consumption, increase the proportion of renewable resources consumption, decrease contaminative consumption and environmental costs, and then lay the foundation for improving the environment and achieving good interaction. Therefore, the study of environmental accounting information disclosure of companies in steel industry is of great significance to the enrichment of environmental accounting theory and control ability.

\section{Current Status Of EnVIRONMENTAl AcCounting INFORMATION DISCLOSURE}

\section{A. Sample Selection}

Environmental accounting information disclosure plays the most important role in heavy polluting industries. It is especially true for the steel industry. It is representative of one of the 16 categories of heavy pollution industries. Therefore, listed companies in the steel industry are taken as research samples. By the end of 2017, there were 43 steel companies listed on the Shenzhen Stock Exchange and the Shanghai Stock Exchange, including 20 in Shenzhen and 23 in Shanghai. One of the *ST companies had serious economic problems, so it was excluded. The remaining 42 steel plate listed companies, including 23 Shanghai stock markets in Shenzhen are analyzed. In the present paper, the prospectus, annual report and social responsibility book of 42 sample companies were collected to analyze the content and methods of environmental accounting information disclosure of listed companies in the steel industry. The data used mainly come from Sohu Securities, Juchao Information Network, Shenzhen Stock Exchange website, Shanghai Stock Exchange website and various corporate websites.

\section{B. Environmental Accounting Information Disclosure Methods}

China's environmental accounting information disclosure mainly adopts two modes: one is the independent reporting mode, and the other is the supplementary reporting mode. Through the research and analysis of 42 sample companies, it 
is known that China's steel industry companies disclose environmental information mainly through the three methods of prospectus, annual report and social responsibility report. There is no uniform regulation on the choice of disclosure mode, and there are some differences. The disclosure of the prospectus and the disclosure of the annual report belong to the supplementary reporting mode, and the disclosure of the social responsibility report belongs to the independent reporting mode.

The number and proportion of environmental accounting information disclosures of listed companies in the domestic steel industry from 2014 to 2016 showed a steady upward trend. Specifically, in the three years from 2014 to 2016, an average of $82.54 \%$ of companies disclosed environmental information in the prospectus. Because China's State Environmental Protection Administration issued a notice to relevant parties, the percentage of companies that expressed environmental accounting information in the prospectus was relatively high. Only a small number of enterprises did not describe environmental issues in accordance with regulations. In 2014, 34 companies disclosed environmental information in the prospectus, accounting for $80.95 \%$ of the sample, and increased to 36 in 2016 , and the proportion rose to $85.71 \%$. This shows that the company's environmental awareness has been improved to some extent. But unfortunately, the environmental information disclosed in the prospectus is mainly textual description, and the quantity is small and the quality is poor. In general, most steel industry companies in China will disclose environmental accounting information, which may have certain differences in the specific modes and contents, and the quality is high or low.

\section{Environmental Accounting Information Disclosure Contents}

The contents of environmental accounting information disclosed by China's steel industry mainly include two forms. First, monetary information is non-monetary information. Monetary information refers to information that is measured only in monetary units, such as environmental investment fees, greening fees, sewage charges, pollution control fees, government environmental incentives and subsidies, etc., and such information is mainly expressed in the notes to the statements in the annual report. Non-monetary information refers to textual expressions that are not only measured in monetary units. The content includes the company's predetermined environmental goals, specific environmental measures taken, and environmental benefits achieved. Such information is generally reported in independent social responsibility and Disclosure in the report of the board of directors.

\section{EXISTING Problems AND Possible ReAsons}

In this section, the existing problems are pointed out and the possible reasons causing the problems are also analyzed.

\section{A. Existing Problems in Environmental Accounting Information Disclosure}

First, environmental accounting information disclosure lacks a unified pattern. At present, China's steel industry companies mainly adopt two modes of environmental accounting information disclosure: one is the independent reporting mode, which is to compose information by compiling a separate environmental report; the other is the supplementary reporting mode, which means that the enterprise is based on the original financial reporting system. In which the environmental information section is added. Through the analysis of the status quo of disclosure in the previous chapter, we can find that the state does not clearly formulate corresponding regulations on the choice of disclosure mode. Only the CSRC stipulates that "listed companies must disclose the contents related to environmental accounting information when issuing the prospectus" This kind of regulation is too general and does not have practical guidance. It makes the choice of disclosure mode based on its own preferences, and it is random and uncertain. The confusion of the disclosure model has led to the dispersion of environmental information. The environmental information disclosed by some companies is involved in the prospectus, the report of the board of directors, the notes to the annual report, and the independent social responsibility report. Even the same information is disclosed in each company. Are not the same. This makes it necessary for information users to fully understand the environmental information of the enterprise and collect and read all the reports and materials, which greatly increases the difficulty of using the information. At the same time, due to the lack of a unified disclosure model, many companies disclose information that is not continuous in the year and the content is different in each year. As a result, the continuity and comparability of information is greatly reduced.

Secondly, environmental accounting information disclosure is not comprehensive. There is no standardized regulation on the content of corporate disclosure of environmental information in China. The company has great autonomy and arbitrariness in choosing to disclose content, which leads to the disclosure content is often not comprehensive and incomplete. In order to establish a good social image, most companies tend to focus only on revealing information that has beneficial or no material impact on themselves, such as the company's environmental policy, environmental goals, environmental protection facilities, environmental technology upgrades, etc. The written form of the text is reflected in the report of the board of directors and the notes to the report of the annual report, mainly as a qualitative description. For quantitative information with substantial application significance, such as resource consumption, pollutant discharge, waste disposal and recycling, etc., it is avoided, and no detailed introduction is made. Many negative negative information is only Disclosure will only be made when reporting or being punished. In this case, the practicality of the disclosed information becomes very low, and it is difficult for stakeholders to make an objective and authentic evaluation.

Thirdly, the supervision of environmental accounting information disclosure is not in place. At this stage, China's standards for environmental accounting information disclosure have not yet formed mandatory normative standards, and there is no specific work on environmental information in China. In the disclosure model mentioned in the previous chapter, audit institutions only audit the prospectus and annual report, and 
because most of the content is qualitative information, it is difficult to measure and review with specific standards, so most accounting firms are not too concerned. This information.

\section{B. Possible Reasons for Environmental Accounting Information Disclosure}

Firstly, there is a lack in perfect laws and regulations. Complete laws and regulations are the foundation of corporate environmental accounting information disclosure. It is the basis for supervision and management, and also the vane of corporate activities. In 1989, the Environmental Protection Law of the People's Republic of China was promulgated. In the subsequent development process, China has also promulgated the "Environmental Information Disclosure Measures", "Environmental Impact Assessment Law" and "Pollution Protection Law". However, by analyzing these laws and regulations, we can find that the current laws and regulations in China mainly guide enterprises to disclose environmental accounting information. There are few specific mandatory regulations, so the binding force is weak, which makes the company's mode confusion and content in the actual disclosure process. dispersion. For the steel industry, China's current laws have not yet made exact requirements for the disclosure of environmental accounting information. The basics are mainly sewage treatment and environmental protection incentives. Therefore, the above-mentioned laws apparently constrained and managed the environmental accounting information disclosure of iron and steel enterprises, but the implementation of the actual work did not produce much significance and the operation was weak.

Secondly, the environmental accounting theory system is not sound. The exploration of environmental accounting information disclosure originated in the western developed countries, so their concept system and practice have been relatively sound. In contrast, China's research in related fields started late. Although scholars and scholars in recent years have gradually increased their attention and research, we are still in the embryonic stage in theory and practice. There are two main reasons for this situation. First, environmental accounting combines accounting and environmental economics. It is a discipline that has only recently emerged. Its theoretical foundation covers many subjects such as mathematics and political economy. The process is complex and abstract. At present, Chinese scholars generally study it based on foreign advanced theories and practical experience, lacking in-depth thinking and innovative exploration, so the theoretical system is not complete. Secondly, due to the short development period of environmental accounting, China's establishment of environmental accounting system is still not mature. There is a lot of information in the confirmation, measurement, recording and reporting. It is difficult to express it clearly in currency, which makes the enterprise The difficulty in defining environmental financial information such as environmental assets and environmental costs has greatly increased, resulting in incomplete environmental accounting information disclosed by enterprises.

Thirdly, steel industry firms pay insufficient attention to environmental accounting information disclosure. As a supplier of environmental accounting information, enterprises play a vital role in the quality of the information provided. With the deterioration of the natural environment in recent years and the continuous attention of the community to this issue, the sustainable development model has become an inevitable trend in the world. Under this environment, it is required to integrate social responsibility into the process of pursuing economic benefits. To achieve a harmonious coexistence with the surrounding environment, and strive to unify the two benefits of society and economy. However, due to the "shareholder supremacy" that has been highly praised for a long time, many companies still subtly seek the highest profits as their business objectives. Domestic disclosure of environmental information has not yet formed more mandatory management regulations. Therefore, the establishment of environmental accounting information disclosure system is less autonomy, even if disclosure is often based on its own rights and interests for selective disclosure. Positive information, ignoring or weakening negative information. In addition, financial personnel are also one of the important factors influencing the quality of environmental accounting information disclosure. The lack of sufficient attention and ability of financial personnel to handle related business will also reduce the level of information disclosed.

\section{COUNTER-MEASURES TO ENVIRONMENTAL ACCOUNTING INFORMATION DISCLOSURE}

Counter-measures to environmental accounting information disclosure are proposed to solve the problems in this section.

\section{A. Establish a Good External Disclosure Environment}

Firstly, we should improve laws and regulations related to environmental accounting. Observing the status quo of environmental accounting information disclosure in western developed countries, we can find that strong laws and regulations play an important guiding role in the work of environmental accounting information disclosure. The analysis of the status quo of environmental accounting information disclosure in China's steel industry can also support this view. With the increase of relevant environmental legislation in China in recent years, the information disclosed by enterprises has gradually become standardized. Therefore, if we want to establish a sound environmental accounting information disclosure system, we should eagerly promote relevant legislative work.

Secondly, we should strengthen the supervision of government departments. The government and relevant departments not only have the responsibility of the abovementioned legislation, but should also shoulder the responsibility of supervising the execution of enterprises. Perfect laws and regulations want to maximize their effectiveness, and strong law enforcement supervision is indispensable. In the process of environmental accounting information disclosure, the company often does not voluntarily and faithfully reflect the protection of its own image. Therefore, relevant departments should play their own functions and promote the implementation of their environmental obligations and responsibilities. In addition to the main regulatory authority, the National Environmental Protection Agency, the China Securities Regulatory Commission and the Ministry of 
Finance should also join the regulatory team. Several departments have jointly implemented law enforcement to build a scientific assessment, reward and punishment mechanism, and strive to do regular inspections. Regular evaluation, objective and fair, and clear rewards and punishments. In addition, the audit department and industry associations should establish special auditing standards for environmental accounting as soon as possible, and verify the reliability and authenticity of the environmental accounting information disclosed by listed companies, and provide a factual basis for the public to supervise the implementation of corporate environmental responsibility.

Thirdly, we should increase stakeholder attention to environmental information. Due to the short history of environmental accounting in China, most stakeholders often pay less attention to environmental accounting information when making investment decisions. Moreover, they usually focus on immediate interests rather than on long-term development. Even if they see information about environmental issues, they only know the incident itself unilaterally. They pay little attention or even pay attention to deep-seated problems such as social harm and long-term impact of enterprises. For these reasons, steel industry companies generally only disclose environmental accounting information for the purpose of supervising inspections, and do not pay attention to the quality of information.

\section{B. Improve the Internal Disclosure Management Mechanism}

Firstly, we should strengthen the awareness of corporate environmental accounting information disclosure. At present, the top managers of domestic listed companies generally have insufficient understanding of environmental accounting information disclosure, and this phenomenon exists in heavily polluting industries or other industries. In the eyes of most management, the basic point of financial management of the company is economic interests and the pursuit of profit maximization. Therefore, when economic interests conflict with environmental accounting information disclosure, they often choose to conceal environmental information. At the same time, negative environmental accounting information that is unfavorable to the corporate image is likely to have an impact on the future interests of the company. Therefore, selective disclosure of positive information, hiding and weakening unfavorable content has become a common problem of corporate environmental accounting information disclosure.

Secondly, we should improve the professional quality of accounting staff. Environmental accounting and information disclosure is still a relatively new subject in China. It combines accounting, environmental economics and other disciplines. It has strong comprehensiveness and complexity, which requires accounting professionals to have higher occupations. Literacy and work ability. Environmental accounting involves a wide range of issues. It requires financial personnel not only to master the theoretical knowledge of accounting, but also to study various fields such as environmental governance. Improving the professional quality of financial accountants can be carried out in the following aspects: (1) Organizing financial personnel to conduct centralized training, learning the latest professional knowledge of environmental accounting theory and practice, and regularly inviting professionals to hold lectures to enhance the concept of work energy saving and updating work. (2) Strengthen communication with accounting personnel in western developed countries, arrange opportunities for exchanges and study abroad, combine foreign advanced experience with the actual situation of the company, and truly integrate with the international community. (3) Accounting personnel should also maintain communication with relevant personnel of environmental protection work to understand certain environmental services, so that they can be more accurate when measuring environmental assets, environmental costs and other factors.

\section{CONCLUSIONS}

Nowadays, environmental pollution is becoming more and more serious on a global scale. Smog, global warming, and abnormal weather have become issues of concern in the world in recent years. China also recognizes that we must never repeat the mistake of "polishing after pollution first", actively investing in environmental protection affairs, formulating a policy of sustainable development, and carrying out a series of work related to environmental accounting, but Late development is slow, and environmental accounting and information disclosure still have many unsound areas. Taking this as a background, this paper first briefly introduces the relevant concepts and theoretical basis of environmental accounting information disclosure, and analyses the current status of corporate environmental accounting information disclosure with listed companies in the steel industry. The results show that the steel industry has many problems in the disclosure work. Such as the mode is not uniform, the content is loose and comparable, the supervision of enterprises and government departments is not in place. Hence, economic reforms like the attempt to improve corporate governance and to limit the influence of the state in publicly listed companies are recommended and will help to further improve corporate governance principles in future.

\section{REFERENCES}

[1] J.M. Zhang and I. Destech Publicat, "On Information Disclosure of Enterprise Environmental Accounting in China," 4th International Conference on Economics and Management, 2017, pp. 285-289.

[2] L.H. Yang, X.T. Liang, and I. Destech Publicat, "Study on the Influencing Factors of Environmental Accounting Information Disclosure," International Conference on Economics, Management Engineering and Marketing, 2017, pp. 134-141.

[3] C. Liu, Z. Song, Y. Li, and D. Liu, "Study on the Information Disclosure of Environmental Accounting," 2009.

[4] G.N. Ofoegbu and A. Megbuluba, "Corporate environmental accounting information disclosure in the Nigeria manufacturing firms," International Journal of Management Sciences and Business Research, vol. 5, pp. 208-220, 2016

[5] C. Deegan and B. Gordon, "A study of the environmental disclosure practices of Australian corporations, " Accounting and business research, vol. 26, pp. 187-199, 1996. 